\title{
PENGARUH KOMITE AUDIT, AUDIT INTERNAL, DAN UKURAN PERUSAHAN TERHADAP PENGUNGKAPAN KECURANGAN PADA PERUSAHAAN PERBANKAN YANG TERDAFTAR DI BEI 2018
}

\author{
Mardani $^{1}$, Yesi Mutia Basri' ${ }^{2}$, M Rasuli $^{3}$ \\ yesimutia@gmail.com \\ Fakultas Ekonomi dan Bisnis Universitas Riau
}

\begin{abstract}
This study aims to examine the influence of the Audit Committee, Internal Audit, and Company Size on Disclosure of Disclosure in Banking Companies Listed on the IDX 2018. Disclosure is the dependent variable in this study. Independent variables of this study are the Audit Committee, Internal Audit and Measurement The company. The population of this study The population used in this study is the Banking Company registered in BEI. Samples selected the samples in this study were, the Purposive Sampling Method The subject of the research was the banking companies registered in BEI which amounted to 33 Companies after using the Purposive sampling method. Data were analyzed using Logistic regression analysis. Logistic regression test was used to predict probability events. an event by matching data to logistics. This method is a general linear model that is used binomial regression. to test the effect of independent variables on the dependent variable. The results of the audit committee's research have a significant effect on the disclosure of fraud on banking companies, internal audit has no significant effect on disclosure of fraud on banking companies listed on the Indonesia Stock Exchange in 2017-2018. The size of the internal audit does not have a significant impact on disclosure of fraud. The size of the company has a significant effect on disclosure of fraud on Banking Companies listed on the Indonesia Stock Exchange in 2017-2018. The larger the size of the company, the higher the disclosure of fraud, and vice versa, the smaller the size of the company, the lower the disclosure of fraud
\end{abstract}

Keywords : Audit Committee, Internal Audit, Company Size, Company Disclosure

\begin{abstract}
Abstrak
Penelitian ini bertujuan untuk menguji pengaruh Komite Audit, Audit Internal, dan Ukuran Perusahaan terhadap Pengungkapan Pengungkapan di Perusahaan Perbankan yang Terdaftar di BEI 2018. Pengungkapan adalah variabel dependen dalam penelitian ini. Variabel independen dari penelitian ini adalah Komite Audit, Audit Internal dan Pengukuran Perusahaan. Populasi penelitian ini Populasi yang digunakan dalam penelitian ini adalah Perusahaan Perbankan yang terdaftar di BEI. Sampel yang dipilih Sampel dalam penelitian ini adalah, Metode Purposive Sampling. Subjek penelitian ini adalah perusahaan perbankan yang terdaftar di Bei yang berjumlah 33 Perusahaan setelah menggunakan metode Purposive sampling. Data dianalisis menggunakan analisis regresi logistik. Uji regresi logistik digunakan untuk memprediksi kejadian probabilitas.
\end{abstract}


sebuah acara dengan mencocokkan data dengan logistik. Metode ini adalah model linier umum yang digunakan regresi binomial. untuk menguji pengaruh variabel independen terhadap variabel dependen. Hasil penelitian komite audit berpengaruh signifikan terhadap pengungkapan kecurangan pada perusahaan perbankan, audit internal tidak berpengaruh signifikan terhadap pengungkapan kecurangan pada perusahaan perbankan yang terdaftar di Bursa Efek Indonesia pada 2017-2018. Ukuran audit internal tidak memiliki dampak signifikan pada pengungkapan penipuan. Ukuran perusahaan berpengaruh signifikan terhadap pengungkapan kecurangan pada Perusahaan Perbankan yang terdaftar di Bursa Efek Indonesia pada 2017-2018. Semakin besar ukuran perusahaan, semakin tinggi pengungkapan penipuan, dan sebaliknya, semakin kecil ukuran perusahaan, semakin rendah pengungkapan penipuan.

Kata kunci: Komite Audit, Audit Internal, Ukuran Perusahaan, Pengungkapan Perusahaan

\section{PENDAHULUAN}

Kecurangan (fraud) merupakan fenomena yang selalu menarik untuk dibahas. Praktik kecurangan yang sudah ada sejak dulu dan masih terjadi hingga sekarang. Berbagai peraturan perundangan dibuat untuk mengatasi kecurangan, namun tidak mengurangi tingkat praktek kecurangan. Perkembangan teknologi informasi diikuti dengan berkembangnya praktik kecurangan.

Kasus kecurangan disektor publik dewasa ini makin ramai diberitakan di berbagai media dan surat kabar. Hal ini dibuktikan dengan banyaknya pejabat publik dari pemerintah pusat maupun pemerintah daerah terjerat kasus kecurangan. Lazimnya praktek kecurangan yang banyak terjadi di sektor publik adalah korupsi, selain itu ada juga praktek kecurangan dalam pelaporan keuangan walaupun jarang terdengar oleh publik.

Survai ACFE Indonesia tahun 2016 tentang fraud di Indonesia menunjukkan bahwa korupsi merupakan jenis fraud yang menduduki posisi pertama yang paling banyak terjadi di Indonesia. Kemudian diperingkat kedua adalah ada penyalahgunaan aset (missappropriationasset), dan yang terakhir adalah ada kecurangan laporan keuangan (fraudelent statement). Dari sekian banyaknya kasus kecurangan yang terjadi lembaga/ organisasi yang paling dirugikan atas praktik fraud ini adalah lembaga pemerintah di posisi pertama. Selanjutnya diikuti dengan perusahaan BUMN/BUMD, perusahaan swasta dan organisasi nirlaba/lainnya. Oleh karena itu lembaga yang paling 
dirugikan atas praktek fraud ini adalah lembaga pemerintah (Survai ACFE Indonesia ; 2016, 13-27).

Diantara praktek kecurangan yang pernah terjadi di Indonesia adalah kasus korupsi KTP Elektronik dengan kerugian senilai Rp. 2,3 triliun, kasus mafia pajak senilai Rp. 1,52 triliun, kasus proyek wisma atlet di Hambalang senilai Rp. 463,66 miliar, kasus suap dan tindak pidana pencucian uang oleh Ketua Mahkamah Konstitusi periode 20132018 terhadap beberapa kasus sengketa pilkada di Mahkamah Konstitusi, kasus korupsi simulator SIM dengan total kerugian senilai Rp. 121,83 miliar, dan masih banyak kasus besar lainnya (https://www.kaskus.co.id).

Pada tahun 2017 lalu, berita kecurangan berasal dari salah satu perusahaan Badan Usaha Milik Negara (BUMN) yaitu PT. Garuda Indonesia. Emirsyah Satar yang merupakan mantan Direktur Utama (Dirut) PT. Garuda Indonesia dinyatakan sebagai tersangka kasus korupsi oleh Komisi Pemberantasan Korupsi (KPK) karena telah menerima suap dalam bentuk transfer uang dan asset senilai lebih dari 4 juta dollar AS terkait dengan pengadaan mesin Rolls-Royce untuk pesawat Airbus milik Garuda Indonesia. Kasus tersebut menegaskan masih kentalnya budaya korupsi di perusahaan BUMN (www.kompas.com).

Penerapan mekanisme internal Tata kelola perusahaan yang baik diyakini dapat mencegah fraud. Struktur tata kelola yang memiliki tugas dan tanggung jawab terkait kecurangan adalah komite audit dan audit internal. Komite audit merupakan komite yang ditunjuk oleh perusahaan sebagai penghubung antara dewan direksi dan audit eksternal, auditor internal serta anggota independen yang memiliki tugas untuk memberikan pengawasan auditor. Pelaksanaan fungsi pengawasan dan pemantauan yang efektif oleh komite audit, akan membantu perusahaan/organisasi dalam mencegah fraud kalau komite audit dapat menjalankan tanggung jawabnya dengan baik (Rita Anugerah, 2014).

Whistleblowing adalah pelaporan yang dilakukan oleh anggota organisasi aktif maupun non-aktif mengenai pelanggaran, tindakan ilegal atau tidak bermoral kepada pihak didalam maupun diluar organisasi (Khan, 2009). Pentingnya whistleblowing dalam perusahaan akan bertindak sebagai pemberi peringatan ataupun saksi atas seseorang yang melakukan kecurangan laporan keuangan. Namun hal tersebut sangat jarang dilakukan di dunia kerja. Pemikiran tentang akan dipecat dari pekerjaan, status 
sosial yang nanti akan dijauhi oleh rekan kerja bahkan dapat mengancam hidupnya sendiri dan keluarganya menjadi pilihan yang sulit untuk memberikan kebenaran.

Perusahaan yang besar lebih cenderung memiliki jumlah transaksi dan informasi yang lebih luas sedangkan perusahaan yang kecil lebih cenderung memiliki transaksi dan informasi yang lebih sempit. Artinya sebuah perusahaan dengan ukuran yang besar dapat meningkatkan asimetri informasi yang terjadi di bandingkan dengan perusahaan dengan ukuran kecil (Handoko dan Ramadhani, 2015). Ukuran perusahaan dapat mempengaruhi kelengkapan pengungkapan laporan keuangannya. Perusahaan yang berukuran besar cenderung lebih banyak mengungkapkan butir-butir laporan keuangannya karena mereka memiliki lebih banyak informasi yang dapat diungkapkan dibandingkan perusahaan berukuran kecil. Sehingga pada perusahaan besar cenderung lebih mudah mengungkapkan kecurangan karena semakin ketat pengendalian seiring dengan semakin besarnya ukuran perusahaan

\section{TINJAUAN PUSTAKA}

\section{Kecurangan}

Association of Certified Fraud Examinations (ACFE) mendefinisikan kecurangan (fraud) sebagai perbuatan-perbuatan yang melawan hukum yang dilakukan dengan sengaja untuk tujuan tertentu (manipulasi atau memberikan laporan keliru terhadap pihak) dilakukan orang-orang dari dalam atau luar organisasi untuk mendapatkan keuntungan pribadi ataupun kelompok yang secara langsung atau tidak langsung merugikan pihak lain.

\section{Jenis-Jenis Kecurangan}

\section{a) Korupsi (Corruption)}

Jenis kecurangan ini paling sulit dideteksi karena menyangkut kerjasama atau kesepakatan dengan pihak lain seperti suap dan kolusi. Contoh korupsi antara lain:

1) Penyalahgunaan wewenang/konflik kepentingan (conflict of interest) terjadi melalui permainan pembelian atau penjualan barang/jasa yaitu dengan adanya hubungan antara penjual dan pembeli yang menimbulkan penambahan harga atau fee yang tidak wajar. 
2) Penyuapan (bribery), yaitu pemberian atau janji yang dimaksudkan agar penerima berbuat atau tidak berbuat sesuatu dalam tugasnya yang berlawanan dengan kewenangan dan atau kewajibannya;

3) Penerimaan yang tidak sah/gratifikasi (illegal gratuities), yaitu pemberian atau hadiah yang merupakan bentuk terselubung dari penyuapan. Bentukbentuknya antara lain hadiah perkawinan, hadiah ulang tahun, hadiah perpisahan, hadiah kenaikan pangkat dan jabatan dan lain-lain yang diberikan kepada pejabat.

b) Penyalahgunaan Aset (Asset Missappropriation)

Penyalahgunaan aset dapat berupa pencurian atau penggelapan aset atau harta perusahaan atau pihak lain, misalnya:

1) Larceny atau pencurian uang yang ada di perusahaan atau pencurian atas aset misal aset milik pemerintah yang tidak dikembalikan setelah tidak lagi menjabat;

2) Skimming, yaitu penarahan atas uang sebelum uang tersebut secara fisik masuk ke perusahaan misalnya dengan cara lapping dan penagihan atas piutang yang telah dihapus;

3) Fraudulent disbursement atau pencuri melalui pengeluaran yang tidak sah seperti pembebanan tagihan fiktif, gaji fiktif, biaya perjalanan dinas fiktif, pemalsuan cek, refund fiktif, pembatalan penjualan fiktif;

4) Penyimpangan atas persediaan, contohnya penjualan BBM bersubsidi secara illegal untuk mengambil keuntungan dari perbedaan harga dengan BBM non subsidi;

5) Misuse, atau penyalahgunaan penggunaan aset, misalnya kendaraan dinas atau inventaris kantor digunakan untuk keperluan pribadi.

c) Kecurangan Laporan Keuangan (Fraudulent Statement) ;

Rekayasa laporan keuangan ini biasa dikenal dengan istilah window dressing yaitu dengan merekayasa laporan keunagan perusahaan atau instansi pemerintah untuk menutupi kondisi keuangan sebenarnya guna memperoleh keuntungankeuntungan tertentu yang dilain sisi dapat merugikan kreditor atau investor. Bentuk-bentuk rekayasa laporan keuangan seperti: lebih atau kurang saji aset atau pendapatan, perbedaan waktu pengakuan transaksi, pendapatan fiktif, utang 
atau biaya tersembunyi, pengungkapan yang tidak tepat, dan penilaian yang tidak tepat atas aset.

\section{Komite Audit}

Menurut Arens et al (2010), menjelaskan pengertian komite audit adalah:

"Audit committees is a selected number of members of a company's board of directors whose responsibilities include helping auditors remain independent of management. most audit committees are made up of three to five or sometimes as many as seven directors who are not a part of company management."

Pernyataan tersebut menjelaskan bahwa umumnya komite audit itu terdiri dari tiga atau lima kadang tujuh orang yang bukan bagian dari manajemen perusahaan. Tujuan dibentuknya komite audit yaitu untuk menjadi penengah antara auditor dan manajemen perusahaan apabila terjadi perselisihan.

Sedangkan menurut Peraturan Nomor IX.1.5 dalam lampiran Keputusan Ketua Bapepam Nomor: Kep-29/PM/2004 mengemukakan bahwa: "Komite Audit adalah komite yang dibentuk oleh Dewan Komisaris dalam rangka membantu melaksanakan tugas dan fungsinya”. Berdasarkan definisi-definisi tersebut, maka dapat dijelaskan bahwa komite audit dibentuk oleh dewan komisaris yang bekerjasama dalam melaksanakan tugas dan fungsi dewan komisaris. Salah satu tugasnya yaitu memastikan efektivitas sistem pengendalian intern. Selain itu, komite audit juga bertanggungjawab kepada dewan komisaris.

\section{Audit Internal}

Institut Internal Auditor (IIA) mendefinisikan audit internal sebagai aktivitas independen dan objektif dengan tujuan verifikasi dan konseling, dilakukan secara berurutan untuk berkontribusi pada nilai tambah bagi organisasi dan untuk meningkatkan operasinya (IIA, 2019).

Audit Internal mendukung organisasi dalam mencapai tujuannya melalui pendekatan sistematis dan metodologis untuk mengevaluasi dan meningkatkan efektivitas risiko proses manajemen, kontrol dan manajemen organisasi. Audit Internal dirancang untuk berkontribusi pada implementasi mekanisme kontrol yang efektif dalam entitas. Audit Internal melakukan evaluasi atas efektivitas dan efisiensi, serta 
memberikan saran untuk perbaikan berkelanjutan, melalui identifikasi kelemahan di area manajemen (IIA, 2019).

Audit internal dilakukan oleh orang yang berprofesional yang memiliki pemahaman mengenai budaya, kerja, sistem, dan kegiatan operasional suatu entitas. Aktivitas audit internal memberikan jaminan bahwa pengendalian internal yang dijalankan perusahaan telah cukup memadai untuk memperkecil terjadinya risiko, dan menjamin bahwa kegiatan operasional perusahaan telah berjalan secara efektif dan efisien, serta memastikan bahwa sasaran dan tujuan organisasi tercapai (Hery, 2018: 78).

Menurut Sawyer $(2005 ; 10)$ pengertian pengendalian internal secara umum adalah sebuah penilaian yang sistematis dan objektif yang dilakukan auditor internal terhadap operasi dan kontrol yang berbeda-beda dalam organisasi untuk menentukan apakah (1) informasi keuangan dan operasi telah akurat dan dapat diandalkan; (2) risiko yang dihadapi perusahaan telah diidentifikasi dan diminimalisasi; (3) peraturan eksternal serta kebijakan dan prosedur internal yang bisa diterima telah diikuti; (4) kriteria operasi yang memuaskan telah dipenuhi; (5) sumberdaya telah digunakan secara efisien dan ekonomis; dan (6) tujuan organisasi telah dicapai secara efektifsemua dilakukan dengan tujuan untuk dikonsultasikan dengan manajemen dan membantu anggota organisasi menjalankan tanggung jawabnya secara efektif. Pengendalian internal ini bersifat preventif (untuk mencegah terjadinya hal-hal yang tidak diinginkan), detektif (ntuk mendeteksi dan memperbaiki hal-hal yang tidak diinginkan yang telah terjadi), dan direktif (untuk menyebabkan dan mengarahkan terjadinya hal yang diinginkan).

\section{Ukuran Perusahaan}

Ukuran perusahaan pada dasarnya adalah pengelompokan perusahaan ke dalam beberapa kelompok, diantaranya perusahaan besar, sedang dan kecil. Skala perusahaan merupakan ukuran yang dipakai untuk mencerminkan besar kecilnya perusahaan yang didasarkan kepada total aset perusahaan (Suwito dan Herawaty, 2005).

Ukuran perusahaan adalah skala perusahaan yang dilihat dari total aktiva perusahaan pada akhir tahun. Total penjualan juga dapat digunakan untuk mengukur besarnya perusahaan. Karena biaya-biaya yang mengikuti penjualan cenderung lebih 
besar, maka perusahaan dengan tingkat penjualan yang tinggi cenderung memilih kebijakan akuntansi yang mengurangi laba (Sidharta, 2000).

Penelitian ukuran perusahaan dapat menggunakan tolak ukur aset. Karena total aset perusahaan bernilai besar maka hal ini dapat disederhanakan dengan mentranformasikan ke dalam logaritma natural (Ghozali,2006). Ukuran perusahaan menggambarkan besar kecilnya perusahaan. Besar kecilnya usaha tersebut ditinjau dari lapangan usaha yang dijalankan. Penentuan skala besar kecilnya perusahaan dapat ditentukan berdasarkan total penjualan, total aset, rata-rata tingkat penjualan (Seftianne, 2011).

Perusahaan yang berukuran besar mempunyai berbagai kelebihan dibanding perusahaan berukuran kecil. Kelebihan tersebut yang pertama adalah ukuran perusahaan dapat menentukan tingkat kemudahan perusahaan memperoleh dana dari pasar modal. Kedua, ukuran perusahaan menentukan kekuatan tawar-menawar (bargaining power) dalam kontrak keuangan. Dan ketiga, ada kemungkinan pengaruh skala dalam biaya dan return membuat perusahaan yang lebih besar dapat memperoleh lebih banyak laba (Sawir,2004).

Ukuran perusahaan adalah rata-rata total penjualan bersih untuk tahun yang bersangkutan sampai beberapa tahun. Dalam hal ini penjualan lebih besar daripada biaya variabel dan biaya tetap, maka akan diperoleh jumlah pendapatan sebelum pajak. Sebaliknya jika penjualan lebih kecil daripada biaya variabel dan biaya tetap maka perusahaan akan menderita kerugian (Brigham dan Houston,2001).

\section{KERANGKA PEMIKIRAN}

\section{Pengaruh Komite Audit terhadap Pengungkapan Kecurangan}

Teori keagenan menyebutkan bahwa masalah akan timbul antara hubungan agen dan prinsipal jika terdapat asimetri informasi (ketidakseimbangan informasi). Ketidakseimbangan informasi ini terjadi jika pendistribusian informasi dari agen (manajemen) dan prinsipal yang tidak merata. Selain itu beberapa pendapat juga menyatakan bahwa ketidakseimbangan informasi bisa saja terjadi ketika tujuan agen tidak selaras dengan tujuan yang diinginkan prinsipal. Hal ini disebabkan karena masing-masing individu berusaha untuk mensejahterakan dirinya sendiri, sehingga 
mendorong agen untuk manampilkan informasi yang tidak sesuai dengan kenyataan kepada prinsipal.

Tujuan dibentuknya komite audit adalah untuk menjadi penengah antara agen dan prinsipal. Komite audit dibentuk oleh Dewan Komisaris untuk menjalankan fungsi pengawasan atas kegiatan perusahaan yang terkait dengan penelaahan atas informasi keuangan, pengendalian internal, manajemen risiko, efektivitas auditor internal dan eksternal, dan kepatuhan pada peraturan dan perundang-undangan yang berlaku (Bapepam, Peraturan Nomor IX.1.5, 2004).

Untuk melaksanakan fungsinya tersebut, komite audit yang tunjuk harus independen. Artinya komite audit tidak memiliki kepentingan dalam perusahaan (bukan pemilik atau pengelola). Tidak memiliki saham perusahaan yang ditunjuk ataupun hubungan keluarga dengan salah satu anggota yang di perusahaan. Selain itu komite audit disyaratkan harus memiliki kemampuan dibidang akuntansi dan keuangan. Hal ini bertujuan agar komite audit mampu memberikan penilaian yang independen atas informasi yang diterimanya, maampu mengenali permasalahan dan memberikan solusi yang tepat (Peraturasn OJK No 55, 2015).

Perusahaan yang memiliki komite audit yang independen akan mampu mengurangi kegiatan penyimpangan yang dapat dilakukan manajemen. Sebagaimana yang diutarakan oleh Utami, et al (2019) bahwa komite audit berpengaruh dalam mengungkap kasus kecurangan. Utami, et al menyatakan bahwa semakin banyak komite audit yang memiliki keahlian keuangan maka akan efektivitas komite audit akan semakin meningkat. Sedangkan menurut hasil penelitian Cahyono dan Sulhani (2017) komite audit tidak berpengaruh terhadap pengungkapan kecurangan.

Berdasarkan penjelasan diatas dapat dirumuskan hipotesis sebagai berikut ini : H1 : Komite audit berpengaruh terhadap pengungkapan kecurangan

\section{Pengaruh Audit Internal terhadap Pengungkapan Kecurangan}

Audit Internal adalah suatu fungsi penilaian yang dikembangkan secara bebas dalam organisasi untuk menguji dan mengevaluasi kegiatan-kegiatan sebagai wujud pelayanan terhadap organisasi (Hery, 2018:8).

Aktivitas audit internal yang dijalankan secara efektif akan menjadi sesuatu yang berharga dimata manajemen. Objektivitas, keahlian, dan pengetahuan yang dimiliki oleh 
seseorang auditor internal yang kompeten akan didapat secara signifikan memberi nilai tambah bagi pengendalian internal entitas (Hey, 2018:8). Keseluruhan tujuan pemeriksaan internal adalah untuk membantu segenap anggota manajemen dalam menyelesaikan tanggung jawab mereka secara efektif, dengan memberi mereka analisis, penilaian, saran, dan komentar yang objektif mengenai kegiatan atau hal-hal yang diperiksa.

Dari penjelasan diatas dapat disimpulkan bahwa audit internal memiliki peranan cukup besar atas penyajian laporan keuangan. Ketepatan dan kewajaran atas laporan keuangan yang disajikan menjadi tanggung jawab audit internal. Jika laporan keuangan tidak disajikan secara wajar maka harus dilakukan pemeriksaan oleh audit internal untuk mengungkapkan salah saji/kecurangan (Handayani, 2015).

Dalam hasil penelitian Handayani (2015) menyatakan bahwa audit internal berpengaruh terhadap kecurangan. Semakin efektif audit internal, maka semakin besar peluang mengungkapkan kecurangan. Hasil penilitian ini bertolak belakang dengan hasil penilitian Utami et al (2019) dan Cahyono dan Sulhani (2017) yang menyatakan audit internal tidak berpengaruh terhadap pengungkapan kecurangan.

Berdasarkan penjelasan diatas dapat dirumuskan hipotesis sebagai berikut ini :

H2 : Audit intenal berpengaruh terhadap pengungkapan kecuranganPengaruh Kejelasan Sasaran Anggaran Terhadap Akuntabilitas Pengelolaan Dana Desa

\section{Pengaruh Ukuran Perusahaan terhadap Pengungkapan Kecurangan}

Sebuah perusahaan dengan ukuran yang besar dapat meningkatkan asimetri informasi yang terjadi dibandingkan dengan perusahaan dengan ukuran kecil (Handoko dan Ramadhani, 2015). Dalam penlitian Devi dan Ketut (2014:477) juga menjelaskan ukuran perusahaan dapat mempengaruhi kelengkapan pengungkapan laporan keuangannya. Perusahaan yang berukuran besar cenderung lebih banyak mengungkapkan butir-butir laporan keuangannya karena mereka memiliki lebih banyak informasi yang dapat diungkapkan di bandingkan perusahaan berukuran kecil.

Berdasarkan penjelasan diatas dapat dirumuskan hipotesis sebagai berikut ini :

H3 : Komite audit berpengaruh terhadap pengungkapan kecurangan 


\section{Gambar 1. Kerangka Pemikiran}

\section{Model Penelitian}

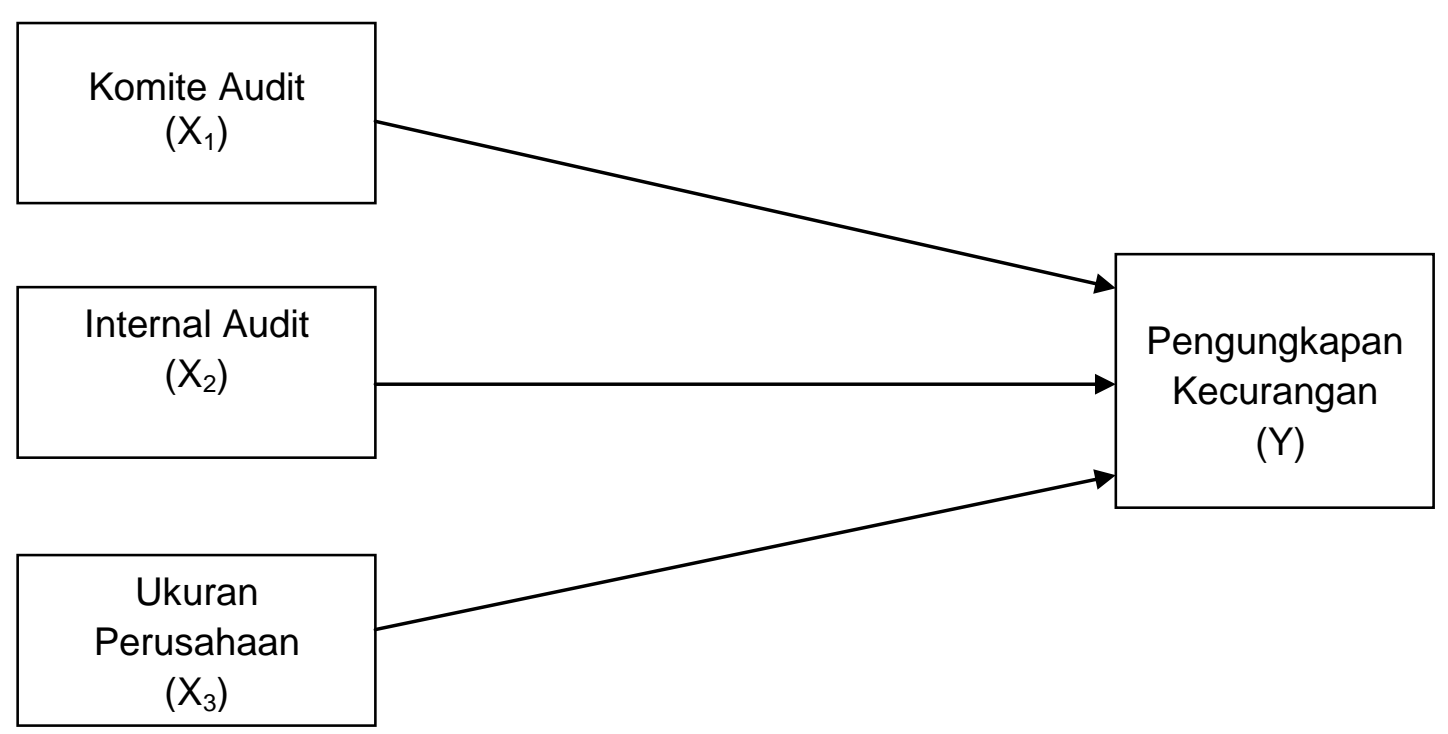

\section{METODE PENELITIAN}

Analisis yang digunakan dalam penelitian ini adalah analisis regresi logistik (logistic regression). Dari pengujian yang dilakukan, maka akan diperoleh persamaan struktural sebagai berikut:

$\operatorname{Ln} P K \frac{P K}{1-P K}=\alpha+\beta 1 \mathrm{KA}+\beta 2 \mathrm{AI}+\beta 3 \mathrm{UP}+\varepsilon$

\section{Keterangan:}

Ln PK $\frac{P K}{1-P K} \quad$ : Dummy variabel pengungkapan kecurangan (Nilai 1 jika ada laporan kecurangan dan nilai 0 jika tidak ada laporan kecurangan)

$\alpha \quad$ : Konstanta

$\beta 1-\beta 3 \quad$ : Koefisien regresi masing-masing faktor

KA : Komite Audit

AI : Audit Internal

UP : Ukuran Perusahaan

$\varepsilon \quad:$ Error

Maka dapat disimpulkan, sampel pada penelitian ini adalah 121 Desa. Sampel dalam penelitian ini adalah desa-desa yang berada di Kabupaten Kuantan Singingi 
dengan pemilihan sampel melalui metode Simple Random Sampling yang menggunakan Microsoft Excel 2010. Yang menjadi subjek penelitian adalah Aparatur Desa yang terdiri dari Kepala Desa, Sekretaris Desa, Kaur Keuangan Desa, dan BPD di setiap Desa. Teknik pengumpulan data dalam penelitian ini dilakukan dengan menggunakan metode survey. Metode survey merupakan metode pengumpulan data primer dengan memberikan kuesioner kepada responden individu (Sugiyono, 2016)

Kuesioner pada penelitian ini menggunakan skala likert. Skala Likert merupakan salah satu bagian dari skala sikap yang didasarkan pada penjumlahan sikap responden dalam merespons pernyataan berkaitan indikator suatu konsep atau variabel yang sedang diukur.

Untuk mengukur pendapat responden digunakan skala lima angka yaitu mulai angka 5 untuk pendapat sangat setuju (SS) sampai dengan angka 1 untuk sangat tidak setuju (STS). Perinciannya adalah sebagai berikut: Angka 1 = Sangat Tidak Setuju (STS), Angka 2 = Tidak Setuju (TS), Angka $3=\operatorname{Netral~(N),~Angka~} 4=$ Setuju (S), Angka $5=$ Sangat Setuju (SS).

\section{HASIL DAN PEMBAHASAN}

Pengungkapan kecurangan merupakan pelaporan salah saji dalam laporan keuangan sebagai akibat dari kelalaian manajemen yang disengaja yang dapat mengurangi integritas informasi keuangan perusahaan. Variabel pengungkapan kecurangan diukur dengan menghitung jumlah kecurangan yang dilaporkan. Pendeteksian kecurangan dapat diketahui dari tiga indikator yaitu 1) Kecurangan laporan keuangan diantaranya biaya dicatat lebih besar dari semestinya, pencatatan bukti transaksi dilakukan tanpa otoritas dari pihak yang berwenang dan harga beli peralatan/ perlengkapan kantor dicatat lebih tinggi. 2) Penyalahgunaan asset diantaranya memasukan kebutuhan lain yang tidak sesuai kedalam belanja peralatan gedung kantor, menggunakan kuitansi kosong atas pembelian bahan perlengkapan kantor serta perlengkapan dan peralatan kantor yang dibeli tidak sesuai dengan spesifikasi yang seharusnya dibeli. 3) Korupsi diantaranya suatu transaksi memiliki bukti pendukung ganda, ditemukan adanya pengeluaran tanpa dokumen pendukung dan sisa anggaran dibagikan kepada pegawai sebagai bonus. Untuk mengukur jumlah 
pelaporan tersebut maka variabel pengungkapan kecurangan akan diukur menggunakan variabel dummy.

Dari hasil pengujian yang dilakukan, diperoleh deskripsi mengenai pengungkapan kecurangan pada perusahaan Perbankan yang terdaftar di BEI pada tahun 2017-2018 adalah sebagai berikut:

Tabel 4.1 Distribusi Frekuensi Variabel Pengungkapan Kecurangan Pada Perusahaan Perbankan Yang Terdaftar di BEI pada Tahun 2017-2018

\begin{tabular}{|c|c|c|}
\hline $\begin{array}{c}\text { Pengungkapan } \\
\text { Kecurangan }\end{array}$ & Frekuensi & $\begin{array}{c}\text { Persentase } \\
\text { (\%) }\end{array}$ \\
\hline Ya & 26 & 39,4 \\
\hline Tidak & 40 & 60,6 \\
\hline Jumlah & 66 & 100,0 \\
\hline
\end{tabular}

Sumber: Hasil Pengolahan Data, 2020.

\section{Komite Audit}

Komite audit merupakan komite yang dibentuk oleh dewan komisaris yang bekerjasama dalam melaksanakan tugas dan fungsi untuk memastikan efektivitas sistem pengendalian intern. Dalam penelitian ini, variabel komite audit diukur dengan menggunakan jumlah rapat komite audit yang dilaksanakan selama setahun.

Dari hasil pengujian yang dilakukan, diperoleh deskprisi tentang variabel komite audit pada perusahaan Perbankan yang terdaftar di BEI pada tahun 2017-2018 adalah sebagai berikut:

Tabel 4.2 Deskriptif Statistik Variabel Komite Audit Pada Perusahaan Perbankan Yang Terdaftar di BEI pada Tahun 2017-2018

\begin{tabular}{|c|c|c|c|c|c|}
\hline Variabel & N & Minimum & Maximum & Mean & $\begin{array}{c}\text { Std. } \\
\text { Deviation }\end{array}$ \\
\hline Komite Audit & 66 & 2,00 & 23,00 & 9,5303 & 4,94032 \\
\hline
\end{tabular}

Sumber: Hasil Pengolahan Data, 2020.

Dari Tabel 4.2 dapat dilihat bahwa dari 66 data pengamatan diketahui bahwa paling sedikit perusahaan perbankan melakukan rapat komite audit sebanyak 2 kali setahun dan paling banyak adalah 23 kali dalam satu tahun dengan rata-rata melakukan rapat tahunan sebanyak 9 kali dan standar deviasi 4,94 kali. Rapat komite audit idealnya diadakan minimal sekali dalam 3 (tiga) bulan dan dihadiri minimal lebih dari $1 / 2$ (satu per dua) jumlah anggota. Setiap rapat komite audit dituangkan di dalam 
risalah rapat serta ditandatangani oleh seluruh anggota komite audit yang hadir dan disampaikan kepada dewan komisaris.

\section{PEMBAHASAN}

Berdasarkan hasil analisis data dan pengujian hipotesis yang telah dilakukan, maka dapat diambil kesimpulan bahwa:

Dari hasil penelitian dan pembahasan yang telah dipaparkan pada BAB sebelumnya, maka dapat ditarik kesimpulan dari hasil penelitian ini sebagai berikut:

1. Komite audit berpengaruh signifikan terhadap pengungkapan kecurangan pada Perusahaan Perbankan yang terdaftar pada Bursa Efek Indonesia pada tahun 2017-2018. Semakin besar komite audit maka pengungkapan kecurangan akan semakin tinggi dan sebaliknya, semakin kecil komite audit maka pengungkapan kecurangan akan semakin rendah.

2. Audit internal tidak berpengaruh signifikan terhadap pengungkapan kecurangan pada Perusahaan Perbankan yang terdaftar pada Bursa Efek Indonesia pada tahun 2017-2018. Besar kecilnya audit internal dampaknya tidak berarti dalam pengungkapan kecurangan.

3. Ukuran perusahaan berpengaruh signifikan terhadap pengungkapan kecurangan pada Perusahaan Perbankan yang terdaftar pada Bursa Efek Indonesia pada tahun 2017-2018. Semakin besar ukuran perusahaan maka pengungkapan kecurangan akan semakin tinggi dan sebaliknya, semakin kecil ukuran perusahaan maka pengungkapan kecurangan akan semakin rendah.

\section{PENUTUP}

Penelitian ini bertujuan untuk melihat bertujuan untuk menguji pengaruh Komite Audit, Audit Internal, dan Ukuran Perusahaan terhadap Pengungkapan Kecuarangan Pada Perusahaan Perbankan Yang Terdaftar Di BEI 2018. Pengungkapan Kecurangan adalah Variabel dependen dalam Penelitian Ini. Variabel independen dari penelitian ini adalah Komite Audit, Audit Internal dan Pengukuran Perusahaan.. Populasi penelitian ini Populasi yang digunakan dalam penelitian ini adalah Perusahaan Perbankan yang terdaftar di BEI. Sampel dipilih Sampel dalam penelitian ini adalah dengan, Metode Purposive Sampling. Yang menjadi subjek penelitian adalah Perusahaan 
perbankan yang terdaftar di Bei yamg berjumlah 33 Perusahaan setelah menggunakan Metode Purposive sampling. Data dianalisis dengan menggunakan analisis regresi Logistik Adapun saran penelitian sebagai berikut: Berdasarkan evaluasi atas hasil penelitian dan keterbatasan-keterbatasan yang ada dalam penelitian ini, beberapa saran yang diharapkan dapat menjadi bahan pertimbangan untuk peneliti selanjutnya, antara lain:

Dari hasil penelitian dan kesimpulan tersebut diatas, maka beberapa saran yang dapat dikemukakan dalam penelitian ini adalah sebagai berikut:

1. Bagi investor

Investor perlu memperhatikan keberadaan komite audit independen serta keahliannya dalam pengungkapan kecurangan pelaporan keuangan, menilai kembali tata kelola perusahaan untuk memutuskan apakah ingin berinvestasi diperusahaan tersebut atau tidak.

2. Bagi perusahaan

Pihak manajemen perusahaan diperlukan untuk meningkatakan pemahaman tentang berbagai bentuk penyimpangan yang terjadi melalui sosialisasi dan asistensi. Disamping itu juga dinilai perlu adanya pemberlakuan sanksi hukum yang tegas bagi pelaku kecurangan.

3. Bagi peneliti selanjutnya

Peneliti selanjutnya diharapkan dapat meanmbah variabel-variabel lain yang mungkin dapat memengaruhi pengungkapan kecurangan pelaporan keuangan dengan metode dan alat analisis yang berbeda.

\section{DAFTAR PUSTAKA}

Aksi-Coruption Forum (IACF) Tahun 2010 kin, Bactiar. 2006. Pengaruh Sikap Profesionalisme Internal Auditor Terhadap Peranan Internal Auditor Dalam Pengungkapan Temuan Audit. Jurnal Bisnis, Manajemen dan Ekonomi, Vol. 7, No. 3, pp. 792-810. 
ACFE (Association of Certified Fraud Examiners). 2014. Fraud Examiners Manual. Global Fraud Study. Data Elektronik diakses dari www.acfe.com/rttn. Ed. Austin. Texas.

Achmadi, Hanif Rizal. 2017. Pengaruh Peran Audit Intern dan Efektivitas Pelaksanaan terhadap Kecenderungan Kecurangan Akuntansi. Jurnal Ilmiah Riset Akuntansi, Vol.6 No.05.

Arens, Alvin A., Randal J.Elder, Mark S. Beasly. 2009. Auditing dan Jasa Assurance Pendekatan Terintegrasi. Jilid I. Ed.12. Jakarta: Erlangga.

Anugerah, Rita. 2014. Peranan Good Corporate Governance dalamPencegahan Fraud. JurnalAkuntansi, Vol. 3, No. 1:101-113.

Dadang Solihin. 2007. Anggaran Berbasis Kinerja dalam Perencanaan dan Penganggaran Pembangunan.

Davis Gordon B. 1994. Manajement System Information, PT. Midas Surya Grafindo. Jakarta.

Ghozali, Imam. 2018. Aplikasi Analisis Multivariat dengan Program IBM SPSS 25. Badan Penerbit Universitas Diponegoro, Semarang.

Ghozali, Imam dan Hengky Latan. 2014. Partial Least Squares, Konsep, Teknik, dan Aplikasi SmartPLS 3.0. Universitas Diponegoro.

Joseph, Oguda Ndenge., Odhiambo, Albert., dan John, Byaruhanga. 2015. Effect Of Internal Control on Fraud detection and Prevention in District Treasuries of Kakamega Country. International Journal of Business and Management Invention. Vol.4,No.1. p-ISSN : 2319-801X

Kartika, Sekar Niken., \& Sudarno. 2014. Analisis Pengalaman Pra Komite Audit Terhadap Pendeteksian Kecurangan Pelaporan Keuangan. Diponegoro Journal of Accounting. 3 (3).1-10.

Li, J., Mangena, M., \& Pike, R. (2012). The effect of audit committee characteristics on intellectual capital disclosure. The British A ccounting Review, Vol. 44 No. 2, pp. 98-110.

Nurharyanto. 2015 (LPFA). Pelatihan Fraud Auditing. Tk. Dasar Modul 1,2, dan 3. Jakarta: Lembaga Pengembangan Fraud Auditing (LPFA). 
Nurhasanah. 2016. Efektivitas Pengendalian Internal, Audit Internal, Karakteristik Instansi, dan Kasus Korupsi (Studi Empiris di Kementrian/Lembaga). Jurnal Tata Kelola dan Akuntabilitas Keuangan Negara.Vol. 2. No 1

Onulaka, Paul N. 2015. Internal and External Audit Effectiveness in Fraud Detection through Continuous Auditing. International Journal of Management Sciences Vol. 6 No. 10 , ISSN : $462-475$

Petrascu, Daniela., and Alexandra Tieanu. 2014. The Role of Internal in Fraud in Fraud Prevention and Detection. Procedia Economics and Finance. 489-497

Prasetyo, Adrian Budi.2014. Pengaruh Karakteristik Komite Audit Dan Perusahaan Terhadap Kecurangan Pelaporan Keuangan.Jurnal Akuntansi Dan Auditing. 11 (1):1-24.

Ruin, Joseph Eby. 2009. Internal Auditing. Malaysia: Leeds Publications.

Sawyer, Lawrence B., Mortimer AD., James HS. 2005. Internal Auditing. Jakarta: Salemba Empat.

Suginam. 2016. Pengaruh Audit Internal Terhadap Pencegahan Fraud. Pelita Informatika Budi Darma, Vol. XV No. 1 ISSN : 2301-9425

Tunggal, Amin Wijaya. 2000. Audit Manajemen Kontemporer. Jakarta; Harsindo.

Tunggal, Amin Wijaya. 2016. Pencegahan dan Pendeteksian Kecurangan. Jakarta; Harvarindo.

Utami dkk. 2019. Efektifitas Komite Audit dan Audit Internal terhadap Kasus Kecurangan dengan Whistleblowing system sebagai Variabel Pemoderasi. Jurnal Akuntansi Udayana. Volume 26.2

Zhang, Y., Zhou, J., \& Zhou, N. (2007). Audit committee quality, auditor independence, and internal control weaknesses. Journal of Accounting and Public Policy, Vol. 26 No. 3, pp. $300-327$.

www.kaskus.co.idwww.kompas 